\title{
The effects of a high-animal- and a high-vegetable-protein diet on mineral balance and bowel function of young men
}

\author{
BY W. VAN DOKKUM, ANNEKE WESSTRA, R. LUYKEN \\ AND R. J. J. HERMUS \\ Department of Human Nutrition, TNO-CIVO Toxicology and Nutrition Institute, \\ PO Box 360, 3700 AJ Zeist, The Netherlands
}

(Received 8 July 1985 - Accepted 15 April 1986)

\begin{abstract}
1. Twelve young men were given for periods of $20 \mathrm{~d}$, each of three mixed diets, namely a low-protein (LP) diet $(9 \%$ total energy as protein, $67 \%$ of animal origin), a high-animal-protein (HA) diet $(16 \%$ total energy as protein, $67 \%$ of animal origin) and a high-vegetable-protein (HV) diet $(16 \%$ total energy as protein, $67 \%$ of vegetable origin). Retention of calcium, magnesium, iron, zinc and copper as well as various bowel function indices were investigated during each dietary period.

2. Neither the HA diet nor the HV diet changed the retention of the minerals considerably. Only Fe balance decreased significantly on the HV diet.

3. Substituting the HV diet for the HA diet resulted in significant increases in faecal wet weight $(17 \mathrm{~g} / \mathrm{d})$, defaecation frequency $(0.12$ stools $/ \mathrm{d})$, faecal volatile fatty acids $(2.6 \mathrm{mmol} / \mathrm{d})$ and a decrease in faecal bile acids $(128 \mu \mathrm{mol} / \mathrm{d})$.

4. It is concluded that a HV diet, rather than a HA diet is to be recommended with respect to bowel function, whereas the HV diet does not necessarily have a significant influence on mineral retention.
\end{abstract}

For a number of minerals and trace elements recommended daily allowances (RDA) have been formulated. Various dietary factors are known to influence mineral or trace element availability (Rosenberg \& Solomons, 1982). These influences are of importance in the evaluation of the RDA of trace elements and minerals. It is known that an increased protein intake may result in enhanced urinary calcium excretion and a negative $\mathrm{Ca}$ balance (Wachman \& Bernstein, 1968; Hegsted et al. 1981; Linkswiler et al. 1981). Little information is available on the influence of protein intake on mineral balance other than $\mathrm{Ca}$. The RDA for protein is slightly different in various countries. For The Netherlands the protein RDA for male adults is $65-70 \mathrm{~g}$ (9-10\% energy total), UK recommendations amount to $63-72 \mathrm{~g} \mathrm{(10 \%} \mathrm{total} \mathrm{energy),} \mathrm{and} \mathrm{US} \mathrm{recommendations} \mathrm{are} 56$ g protein $(8 \%$ total energy) (International Union of Nutrition Sciences, 1983). The actual intake mostly exceeds the RDA. In The Netherlands, protein intake often reaches values of 14-16\% total energy (Van Dokkum, 1984). The effect of increasing protein intake from an RDA level to the actual intake level on mineral balance is not known. Because of the beneficial influence dietary fibre may have on bowel function, it is generally recommended to increase the dietary fibre intake in Western food patterns (Heaton, 1983). One of the ways to achieve this is to increase vegetable (protein) products and to decrease animal protein intake. This change in dietary pattern is one of the recommendations in The Netherlands (Van Dokkum, 1984). The effect of this proposed change on mineral balance has not yet been studied.

In the present paper the results are presented of experiments regarding the influence on mineral utilization and bowel function when both dietary changes are brought about.

\section{METHODS}

Details of the experimental design are shown in Table 1. Twelve healthy male volunteers (mean age 23 (SE 2) years, weight 72 (SE 7) kg, height 1.82 (SE 0.08) $\mathrm{m}$ and 15 (SE 2)\% body fat) participated. The dietary change from protein intake at the RDA level to $16 \%$ total 
Table 1. Experimental design*

\begin{tabular}{|c|c|c|c|}
\hline $\begin{array}{l}\text { Experimental period... } \\
\text { Diet... }\end{array}$ & $\begin{array}{c}1 \\
\text { Low-protein } \\
\text { (LP) }\end{array}$ & $\begin{array}{c}2 \\
\text { High-animal- } \\
\text { protein } \\
\text { (HA) }\end{array}$ & $\begin{array}{c}3 \\
\text { High-vegetable- } \\
\text { protein } \\
(\mathrm{HV})\end{array}$ \\
\hline Duration (d) & 20 & 20 & 20 \\
\hline \multicolumn{4}{|l|}{ Protein intake: } \\
\hline$\%$ of total energy & 9 & 16 & 16 \\
\hline $\mathrm{g} / \mathrm{d}$ & 63 & 120 & 125 \\
\hline Animal:vegetable protein & $2: 1$ & $2: 1$ & $1: 2$ \\
\hline Blood sampling & $\dagger$ & $\dagger$ & $\dagger$ \\
\hline Urine and faecal collections & Last $8 \mathrm{~d}$ & Last $8 \mathrm{~d}$ & Last $8 \mathrm{~d}$ \\
\hline
\end{tabular}

* The study was carried out with four volunteers at a time and replicated twice (with other subjects), resulting in three experiments with four volunteers each. Only pooled values are given for all twelve volunteers.

$\dagger$ On two consecutive days and the end of each period.

energy as protein was evaluated in the first two experimental periods, the effect of substituting the diet with a high amount of animal protein (HA) with one containing a high amount of vegetable protein (HV) was studied in the last two experimental periods; each experimental period lasted $20 \mathrm{~d}$. In the first experimental period a protein intake at the RDA level was achieved by giving a 'low-protein' (LP) diet; high-protein diets were given during the other periods.

We aimed at providing a habitual Dutch diet without supplementation (e.g. minerals); thus, the results of the study may have practical consequences with regard to dietary recommendations. In other words, when the dietary changes mentioned are brought about there is not merely a change in protein intake, but other dietary components are different as well. Results are therefore a reflection of the combined effects of various dietary factors on mineral balance and bowel function. Also this 'practical' approach means that we had the same order of consumption for all volunteers as we were only interested in the dietary changes mentioned and not, for example, in the effects of replacing a high-vegetable-protein diet by a high-animal-protein diet.

The balance study was carried out in three consecutive periods of $20 \mathrm{~d}$. During each period the mineral balance of the subjects was determined by analysing individual duplicate dietary samples (for each subject twice) and 8-d faecal and urinary mineral excretions (subdivided into two periods of 4-d sample collections). Thus the first $12 \mathrm{~d}$ of each dietary treatment served as a period of adaption to the dietary change. The subjects gave informed written consent. They were housed in the Institute's controlled metabolic ward but they continued their normal daily routines. Before the study the volunteers passed a clinical examination and a nutritional evaluation; all subjects were apparently healthy. The routine haematological values were all within normal ranges.

\section{EXPERIMENTAL, PROCEDURE}

During each $20 \mathrm{~d}$ period the diet was constant and identical for all volunteers with minor differences between subjects regarding sugar, soft-drinks and jelly. These products were also supplied when there was a reduction in body-weight of more than $2 \%$ compared with the weight at the start of the study. The composition of the three experimental diets is given in Table 2, and the diet characteristics, based on analysis of individual duplicate samples, in Table 3. 
Table 2. Composition ( $g$ ) of the experimental diets

(Mean daily values)

\begin{tabular}{|c|c|c|c|}
\hline $\begin{array}{l}\text { Experimental period... } \\
\text { Diet... }\end{array}$ & $\begin{array}{c}1 \\
\text { Low-protein }\end{array}$ & $\underset{\substack{\text { High-animal- } \\
\text { protein }}}{2}$ & $\begin{array}{c}3 \\
\underset{\text { High-vegetable- }}{\text { protein }}\end{array}$ \\
\hline \multicolumn{4}{|l|}{ Breakfast } \\
\hline Two rolls & $2 \times 40$ & $2 \times 40$ & $2 \times 40$ \\
\hline Cheese & 30 & - & 30 \\
\hline Pork roast & - & 30 & - \\
\hline Peanut butter & - & 14 & 14 \\
\hline Orange juice & 125 & 150 & 150 \\
\hline \multicolumn{4}{|l|}{ lunch } \\
\hline Three rolls & $3 \times 40$ & $3 \times 40$ & $3 \times 40$ \\
\hline Cheese & 30 & 30 & 30 \\
\hline Ham (raw) & 15 & - & 15 \\
\hline Ham (snoked) & - & 20 & - \\
\hline Chicken meat & $\ldots .$. & 25 & - \\
\hline Jelly & 30 & - & 14 \\
\hline Orange juice & 125 & - & 150 \\
\hline Custard (low fat) & 150 & 150 & 150 \\
\hline Curd shake & - & 145 & - \\
\hline \multicolumn{4}{|l|}{ Dinner } \\
\hline Potatoes & 200 & 200 & 200 \\
\hline Vegetables* & & & \\
\hline Hamburgert & 100 & 150 & 165 \\
\hline Margarine & 15 & 15 & 15 \\
\hline Ice cream & 50 & - & - \\
\hline Curd and custard & - & 185 & - \\
\hline Canned fruit & $\cdots .$. & - & 100 \\
\hline 1 roll & 40 & 40 & 40 \\
\hline \multicolumn{4}{|l|}{ During the day } \\
\hline Margarine & 35 & 30 & 30 \\
\hline Whisky & 70 & 70 & 70 \\
\hline Coffee (instant) & 3 & 3 & 3 \\
\hline Tea (instant) & 0.9 & 0.9 & 0.9 \\
\hline Sugar & 25 & 25 & 25 \\
\hline Whipped cream & 25 & - & 25 \\
\hline Rye bread & 33 & - & - \\
\hline Jelly & 14 & - & - \\
\hline Fibre biscuits & - & 15 & - \\
\hline Cake & - & - & 25 \\
\hline Raisins & - & - & 35 \\
\hline Soft drinks & $2 \times 200$ & $2 \times 200$ & $2 \times 200$ \\
\hline Canned fruit & - & 100 & - \\
\hline
\end{tabular}

* Rotating order for every $4 \mathrm{~d}$; day 1: $100 \mathrm{~g}$ string beans, $7 \mathrm{~g}$ margarine, $100 \mathrm{~g}$ apple sauce; day 2:30 $\mathrm{g}$ lettuce, $45 \mathrm{~g}$ carrot salad, $45 \mathrm{~g}$ celeriac salad, $20 \mathrm{~g}$ dressing; day 3: $100 \mathrm{~g}$ sliced beans, $7 \mathrm{~g}$ margarine, $100 \mathrm{~g}$ apple sauce; day 4: $100 \mathrm{~g}$ carrots, $7 \mathrm{~g}$ margarine, $100 \mathrm{~g}$ apple sauce.

$\dagger$ Hamburger: LP and HA diets $(\mathrm{g} / \mathrm{kg}): 300$ beef, 300 pork, 200 fat (beef), 100 egg protein, 100 water; HV diet : 400 beef, 170 soya-bean concentrate, 130 lard, 300 water.

For the LP diet a special low-protein bread was prepared; a higher protein intake in the HA period was realized by increasing the amount of meat and meat products. In the last period (HV), bread was prepared with (g/ kg dry weight) 150 wheat gluten and 200 soyabean protein isolate; in the hamburger $170 \mathrm{~g}$ soya-bean-protein concentrate (" textured procon') $/ \mathrm{kg}$ was incorporated. In experimental periods 2 and $3, \mathrm{HA}$ and HV diets were adapted to reach animal protein: vegetable protein values of $2: 1$ and $1: 2$ respectively. The 
Table 3. Characteristics of the various experimental diets

(Mean daily values)

\begin{tabular}{|c|c|c|c|}
\hline $\begin{array}{l}\text { Experimental period... } \\
\text { Diet... }\end{array}$ & $\begin{array}{c}1 \\
\text { Low-protein }\end{array}$ & $\begin{array}{l}2 \\
\begin{array}{l}\text { High-animal- } \\
\text { protein }\end{array}\end{array}$ & $\begin{array}{c}3 \\
\begin{array}{c}\text { High-vegetable- } \\
\text { protein }\end{array}\end{array}$ \\
\hline Energy (MJ) & 11 & 12 & 12 \\
\hline Total protein $(\%$ energy) & 9 & 16 & 16 \\
\hline Total fat ( $\%$ energy) & 37 & 36 & 36 \\
\hline $\begin{array}{l}\text { Total available carbohydrate } \\
(\% \text { energy) }\end{array}$ & 54 & 48 & 48 \\
\hline Dietary fibre (g NDF) & 15 & 15 & 21 \\
\hline Calcium (mg) & 930 & 956 & 989 \\
\hline Magnesium (mg) & 233 & 302 & 360 \\
\hline Iron $(\mathrm{mg})$ & $10 \cdot 6$ & $11 \cdot 4$ & 166 \\
\hline Zinc (mg) & $9 \cdot 0$ & 12.5 & $12 \cdot 2$ \\
\hline Copper (mg) & 1.07 & 1.29 & $2 \cdot 28$ \\
\hline \multicolumn{4}{|l|}{ Protein (\% of total protein): } \\
\hline Meat & 29 & 36 & 15 \\
\hline Milk & 38 & 33 & 17 \\
\hline Vegetable & 33 & 31 & 68 \\
\hline
\end{tabular}

Table 4. Faecal indices of twelve human subjects fed on low-protein ( $L F)$, high-animal-protein $(H A)$ and high-vegetable-protein $(H V)$ diets

(Mean values and standard deviations)

\begin{tabular}{|c|c|c|c|c|c|c|}
\hline \multirow[t]{2}{*}{$\begin{array}{l}\text { Experimental period } \uparrow \ldots \\
\text { Diet... }\end{array}$} & \multicolumn{2}{|c|}{$\begin{array}{l}1 \\
\mathrm{LP}\end{array}$} & \multicolumn{2}{|c|}{$\begin{array}{c}2 \\
\mathrm{HA}\end{array}$} & \multicolumn{2}{|c|}{$\begin{array}{c}3 \\
\mathrm{HV}\end{array}$} \\
\hline & Mean & so & Mean & SD & Mean & SD \\
\hline Faecal wet wt $(\mathrm{g} / \mathrm{d})$ & 101 & 25 & $118^{*}$ & 25 & $135^{* *}$ & 33 \\
\hline dry matter of wet faeces & 22 & 3 & 21 & 3 & 22 & 3 \\
\hline $\begin{array}{l}\text { Defaecation frequency } \\
\text { (no. of stools/d) }\end{array}$ & 0.86 & 0.32 & 0.88 & $0 \cdot 27$ & $1 \cdot 00^{*}$ & 0.37 \\
\hline Total VFA (mmol/d) & $10 \cdot 9$ & $4 \cdot 8$ & $12 \cdot 6$ & $4 \cdot 0$ & $15 \cdot 2^{*}$ & $5 \cdot 0$ \\
\hline VFA (mmol $/ \mathrm{kg}$ wet faeces) & 108 & 29 & 107 & 24 & 113 & 24 \\
\hline \multicolumn{7}{|l|}{ Bile acids: } \\
\hline$\mu \mathrm{mol} / \mathrm{d}$ & 601 & 110 & 710 & 140 & $582^{*}$ & 123 \\
\hline $\mathrm{mmol} / \mathrm{kg}$ wet faeces & $5 \cdot 9$ & $1 \cdot 5$ & $6 \cdot 0$ & $1 \cdot 4$ & $43^{* * *}$ & $1 \cdot 4$ \\
\hline
\end{tabular}

VFA, volatile fatty acids.

Mean values were significantly different from those in the preceding experimental period: ${ }^{*} P<0 \cdot 05,{ }^{* *} P<0.01$, $* * * P<0.001$.

$\dagger$ Each experimental period lasted $20 \mathrm{~d}$

food was prepared in the diet kitchen, according to standard procedures, weighed to the nearest $\mathrm{g}$, packed in individual portions and deep-frozen, if necessary. Only demineralized water was allowed, e.g. for coffee and tea. All meals were served at the Institute. Individual urine samples $(24 \mathrm{~h}$ ) were collected in polyethylene ( 2 litre) bottles containing $20 \mathrm{ml} 5 \mathrm{M}$ hydrochloric acid as preservative. Stools were collected in 3-litre plastic buckets; each subject used one bucket for every $4 \mathrm{~d}$, stored at $4^{\circ}$. The stools from each $4 \mathrm{~d}$ period were weighed and carefully homogenized in each bucket, ensuring that no faecal loss or mineral 
contamination took place. Separate composites $(4 \mathrm{~d})$ of urine and stools were made for analysis and stored at $-20^{\circ}$. Blood was withdrawn from the antecubital vein before breakfast after an overnight fast on two consecutive days, at the end of each period.

\section{Analytical procedures}

Urine. From the last two $4 \mathrm{~d}$ composites of each dietary period, samples were taken for $\mathrm{Ca}$, magnesium, iron, zinc and copper analysis by means of atomic absorption spectrophotometry (AAS) (Perkin-Elmer 303).

Faeces. From the last two $4 \mathrm{~d}$ composites of each dietary period, samples were taken for mineral determinations by AAS and moisture determinations by drying on sand; volatile fatty acids (VFA) were determined by gas-liquid chromatography (GLC) (Van de Kamer et al. 1955) and total bile acids by an enzymic method (Van Dokkum et al. 1983). Stool frequency was computed from information obtained from the diaries of the volunteers.

Diets. Portions of the homogenized (individual) duplicate diets were saved for analysis of minerals (by AAS), protein, using an automated KjellFoss (Noel, 1976), fat (Schormüller, 1969), total available carbohydrates (Van de Kamer, 1941), fatty acid composition by GLC (IUPAC, 1979), dietary fibre (Van Soest \& Wine, 1967) and amino-acid composition with an automated amino acid analyser; cysteine and methionine were pretreated with performic acid (Moore, 1963).

For mineral analysis faecal and dietary samples were carefully dried, ashed at $550^{\circ}$ for $2 \mathrm{~h}$, and kept for $1 \mathrm{~h}$ at $550^{\circ}$ after addition of $1 \mathrm{ml} 5 \mathrm{M}-\mathrm{HCl}$. The ash was dissolved in $\mathrm{HCl}$ for the final analysis of the minerals by AAS. This procedure was carried out in duplicate for each sample; for both faecal and dietary samples the coefficient of variation of the duplicates ranged from 2 to $3 \%$.

Blood. The venous blood or serum samples were analysed for haemoglobin (cyanmethaemoglobin method), packed cell volume (micro method), erythrocyte count by a Coulter counter, Ca (Raman \& Chang, 1974), ferritin (Miles et al. 1974), Mg, Cu and Zn (by AAS).

Mineral balance was calculated from 8-d dietary intake and urinary + faecal excretion in each dietary period (sub-divided into two $4 \mathrm{~d}$ periods).

For statistical evaluation the results of each dietary treatment were compared with the preceding treatment by means of analysis of variance (Snedecor \& Cochran, 1967) using Student's $t$ test for paired observations. Thus, subjects acted as their own control.

A working group responsible for human nutrition studies performed at the Institute approved this research.

\section{RESULTS}

The defaecation pattern is shown in Table 4. Substituting the HA diet for the LP diet resulted in a significant increase in faecal wet weight of $17 \mathrm{~g} / \mathrm{d}(P<0.05)$; the other differences observed were not statistically significant. Substituting the HV diet for the HA diet resulted in the following significant changes: an increase in faecal wet weight of $17 \mathrm{~g} / \mathrm{d}$ $(P<0.01)$, an increase in defaecation frequency from 0.88 to 1.00 stools $/ \mathrm{d}(P<0.05)$, an increase in faecal VFA of $2.6 \mathrm{mmol} / \mathrm{d}(P<0.05)$ and a decrease in faecal bile acids of $1.7 \mathrm{mmol} / \mathrm{kg}$ wet faeces $(P<0.001)$ and of $128 \mu \mathrm{mol} / \mathrm{d}(P<0.05)$. The VFA composition $(\mathrm{mmol} / \mathrm{mol})$ was similar in all experimental periods; 660 acetic acid, 140 propionic acid and 110 butyric acid. Table 5 shows the mineral balance values. Substituting the HA diet for the LP diet resulted in a significant increase in urinary $\mathrm{Ca}(P<0.01)$ and in faecal $\mathrm{Mg}$ $(P<0.001), \mathrm{Cu}(P<0.01)$ and $\mathrm{Zn}(P<0.001)$. The balance of the five minerals, however, did not change significantly. Substituting the HV diet for the HA diet resulted in significant 
Table 5. Intake, excretion and balance of calcium, magnesium, iron, zinc and copper $(\mathrm{mg} / \mathrm{d})$ of twelve human subjects fed on low-protein $(L P)$, high-animal-protein $(H A)$ and highvegetable-protein $(\mathrm{HV})$ diets

(Mean values and standard deviations)

\begin{tabular}{|c|c|c|c|c|c|c|}
\hline \multirow[t]{2}{*}{$\begin{array}{l}\text { Experimental period } \dagger \ldots \\
\text { Diet.... }\end{array}$} & \multicolumn{2}{|c|}{$\begin{array}{c}1 \\
\mathbf{L P}\end{array}$} & \multicolumn{2}{|c|}{$\stackrel{2}{\mathrm{HA}}$} & \multicolumn{2}{|c|}{$\begin{array}{c}3 \\
\text { HV }\end{array}$} \\
\hline & Mean & $S D$ & Mean & SD & Mean & SD \\
\hline \multicolumn{7}{|l|}{ Calcium } \\
\hline Intake & 930 & 60 & 956 & 87 & 989 & 76 \\
\hline Urine & 173 & 60 & $216^{* * *}$ & 62 & 221 & 60 \\
\hline Faeces & 664 & 81 & 710 & 94 & 800 & 163 \\
\hline Balance & 93 & 78 & 30 & 142 & -32 & 154 \\
\hline \multicolumn{7}{|l|}{ Magensium } \\
\hline Intake & 233 & 16 & $302^{* * * *}$ & 17 & $369^{* * *}$ & 74 \\
\hline Urine & 115 & 35 & 120 & 36 & $161 * * *$ & 38 \\
\hline Faeces & 113 & 24 & $186^{* * *}$ & 45 & 230 & 77 \\
\hline Balance & 5 & 48 & -4 & 60 & -22 & 56 \\
\hline \multicolumn{7}{|l|}{ Iron } \\
\hline Intake & $10 \cdot 6$ & $1 \cdot 3$ & $11 \cdot 4^{*}$ & 0.8 & $16 \cdot 6^{* * *}$ & 1.0 \\
\hline Urine & $0 \cdot 1$ & 0.02 & $0 \cdot 1$ & 0.02 & $0 \cdot 1$ & 0.02 \\
\hline Faeces & $9 \cdot 0$ & 1.7 & $9 \cdot 7$ & 1.6 & $17 \cdot 1^{* *}$ & 3.6 \\
\hline Balance & $1 \cdot 5$ & 1.5 & 1.6 & $1 \cdot 6$ & $-0 \cdot 6^{*}$ & $3 \cdot 4$ \\
\hline \multicolumn{7}{|l|}{ Zinc } \\
\hline Intake & $9 \cdot 0$ & $2 \cdot 0$ & $12 \cdot 5^{* * *}$ & $1 \cdot 5$ & $12 \cdot 2$ & $2 \cdot 7$ \\
\hline Urine & 0.6 & $0 \cdot 2$ & 0.7 & $0 \cdot 2$ & 0.8 & $0 \cdot 2$ \\
\hline Faeces & 9.0 & $1 \cdot 1$ & $11 \cdot 9^{* * *}$ & $2 \cdot 3$ & $12 \cdot 1$ & $2 \cdot 4$ \\
\hline Balance & -0.6 & $1 \cdot 4$ & -0.1 & $2 \cdot 0$ & -0.7 & $2 \cdot 4$ \\
\hline \multicolumn{7}{|l|}{ Copper } \\
\hline Intake & 1.07 & 0.12 & $1 \cdot 29 * * *$ & 0.13 & $2 \cdot 28^{* * *}$ & 0.22 \\
\hline Urine & 0.05 & 0.01 & 0.05 & 0.01 & 0.05 & 0.01 \\
\hline Faeces & 0.89 & $0 \cdot 13$ & $1 \cdot 10^{* *}$ & 0.27 & $1 \cdot 88^{* *}$ & 0.32 \\
\hline Balance & 0.13 & $0 \cdot 16$ & $0 \cdot 14$ & $0 \cdot 20$ & 0.35 & 0.28 \\
\hline
\end{tabular}

Mean values were significantly different from those in the preceding experimental period: ${ }^{*} P<0 \cdot 05,{ }^{* *} P<0 \cdot 01$, ***P $<0.001$.

$\dagger$ Each experimental period lasted $20 \mathrm{~d}$.

Table 6. Blood* constituents and serum biochemical indices of twelve human subjects fed on low-protein $(L P)$, high-animal-protein $(H A)$ and high-vegetable-protein $(H V)$ diets

(Mean values and standard deviations)

\begin{tabular}{|c|c|c|c|c|c|c|}
\hline \multirow[t]{2}{*}{$\begin{array}{l}\text { Experimental period } \dagger \ldots \\
\text { Diet... }\end{array}$} & \multicolumn{2}{|c|}{$\begin{array}{c}1 \\
\mathbf{L P}\end{array}$} & \multicolumn{2}{|c|}{$\stackrel{2}{\mathrm{HA}}$} & \multicolumn{2}{|c|}{$\begin{array}{c}3 \\
\mathrm{HV}\end{array}$} \\
\hline & Mean & SD & Mean & SD & Mean & SD \\
\hline Haemoglobin (mmol/l) & $9 \cdot 3$ & $0 \cdot 5$ & $9 \cdot 2$ & $0.4^{\circ}$ & $9 \cdot 3$ & 0.5 \\
\hline Packed cell volume & 0.45 & $0 \cdot 02$ & 0.44 & 0.02 & 0.42 & 0.03 \\
\hline Calcium $(\mathrm{mmol} / \mathrm{l})$ & $2 \cdot 4$ & $0 \cdot 1$ & $2 \cdot 4$ & $0 \cdot 1$ & $2 \cdot 4$ & $0 \cdot 1$ \\
\hline Magnesium (mmol/1) & 0.81 & 0.06 & 0.82 & 0.04 & 0.82 & 0.05 \\
\hline $\operatorname{Zinc}(\mu \mathrm{mol} / 1)$ & 16.5 & $3 \cdot 4$ & $17 \cdot 3$ & $3 \cdot 5$ & 16.9 & $3 \cdot 8$ \\
\hline Copper $(\mu \mathrm{mol} / \mathrm{l})$ & $14 \cdot 4$ & $3 \cdot 3$ & 13.8 & $2 \cdot 0$ & $13 \cdot 4$ & $5 \cdot 1$ \\
\hline Ferritin $(\mu \mathrm{g} / 1)$ & 163 & 117 & 158 & 114 & 135 & 104 \\
\hline
\end{tabular}

* Blood was withdrawn at the end of each period indicated.

$\uparrow$ Each experimental period lasted $20 \mathrm{~d}$. 
increases in urinary $\mathrm{Mg}(P<0.001)$ and faecal $\mathrm{Fe}(P<0.01)$ and $\mathrm{Cu}(P<0.01)$; however, the mineral balance was not influenced significantly by this dietary change. Only the $\mathrm{Fe}$ balance was lower on the HV $\operatorname{diet}(P<0.05)$. Urinary excretion of $\mathrm{Fe}, \mathrm{Zn}$ and $\mathrm{Cu}$ was low and constant throughout the study.

In Table 6 the results for blood constituents obtained at the end of each experimental period are presented. All indices were constant in all periods. Although various significant changes in the mineral balance results were observed, serum mineral concentrations were not affected.

\section{DISCUSSION}

The increase in dry weight of the diets $(\mathrm{g} / \mathrm{kg} ; 555,600$ and 630 in the LP, HA and HV diet respectively) may in part explain the increase in faecal wet weight. An additional explanation is the higher amount of dietary fibre in the HV period.

VFA are considered to affect the water-binding capacity in the colon (Forsyth et al. 1978; Hellendoorn, 1978) and the increase in faecal VFA observed in the present study supports this assumption. The composition of the VFA is in good agreement with that found in a previous study (Van Dokkum et al. 1983). Morris et al. (1977) and Saunders \& Betschart (1980) reported the significance of protein as a component of dietary fibre; they particularly considered partially digested protein of vegetable origin as a factor in fibre physiology.

The effect of protein on bile acid excretion has hardly been studied. Cummings et al. (1979) found a non-significant increase of $11 \%$ when replacing a low-animal-protein diet $(63 \mathrm{~g} / \mathrm{d})$ by a high-animal-protein diet $(136 \mathrm{~g} / \mathrm{d})$; a significant increase in bile acid excretion of $100 \%$ resulted from an increase in dietary fibre intake from 22 to $53 \mathrm{~g} / \mathrm{d}$. In the present study the increase in dietary fibre intake from 15 to $21 \mathrm{~g} / \mathrm{d}$ (diets HA to HV) did result in a significant decrease in bile acid excretion. As macronutrients other than dietary protein, which are involved in bile acid metabolism, were almost constant in the HA and HV periods, the observed decrease in bile acid excretion in subjects fed on the HV diet could partly be attributed to the type of protein in the diet. A low concentration of bile acids in the faeces, together with a low excretion per $24 \mathrm{~h}$, may contribute to the prevention of colo-rectal cancer (Zaridze, 1981).

The retention of most minerals did not change significantly as a result of the dietary alterations. Both the increased dietary intake of minerals and the increase in dietary components, such as dietary fibre, seemed to counter balance one another with respect to the influence on mineral retention. The increased urinary $\mathrm{Ca}$ excretion on an increased protein intake (LP to HA diet) is in agreement with the results of other studies (Hegsted et al. 1981; Linkswiler et al. 1981).

Haem-Fe absorption is known to be better than non-haem-Fe absorption (Hallberg, 1981); moreover, haem-Fe facilitates the absorption of non-haem-Fe (Finch, 1977; Hallberg, 1981). The diets with a relatively high animal protein:vegetable protein value, therefore seem to be more favourable with respect to $\mathrm{Fe}$ absorption than a high-vegetable-protein diet. The increase in Fe intake on the HV diet was apparently not sufficient to prevent the significant decrease in $\mathrm{Fe}$ balance. For $\mathrm{Zn}$, the retention was negative in ten of the subjects on the LP diet, possibly because of a marginal $\mathrm{Zn}$ intake. The RDA in the USA for $\mathrm{Zn}$ is $15 \mathrm{mg} / \mathrm{d}$ for male adults; in The Netherlands no officially adopted RDA for $\mathrm{Zn}$ exists.

Regarding the mineral balance data, we conclude that the combined influences of various changes brought about by altering the diets have no substantial effects on mineral retention and mineral status. This conclusion is based on the combined influence of increased mineral intake and higher intake of dietary fibre and protein. 
The recommended increase in the consumption of vegetable protein foods appears to be beneficial to bowel function, as can be concluded from the results of the HV diet compared with the HA diet. Thus a high-vegetable-protein diet, rather than a high-animal-protein diet, is to be recommended with respect to bowel function, whereas it does not necessarily have a significant influence on mineral retention.

The authors wish to thank Miss Francien Schippers, Mrs Liesbeth de Groot, Mr L. van Ginkel and $\mathrm{Mr} \mathrm{H}$. van de Weerd for their technical assistance. The co-operation of the Departments of Clinical Biochemistry (Dr W. H. P. Schreurs) and Food Chemistry (Dr P. Slump) as well as of the twelve subjects is gratefully acknowledged.

\section{REFERENCES}

Cummings, J. H., Hill, M. J., Jivraj, T., Houston, H., Branch, W. J. \& Jenkins, D. J. A. (1979). American Journal of Clinical Nutrition 32, 2086-2093.

Finch, C. A. (1977). Food and Nutrition FAO 3, 12-14.

Forsyth, W. A., Chenoweth, W. L. \& Bennink, M. R. (1978). Journal of Food Science 43, 1470-1472.

Hallberg, L. (1981). American Journal of Clinical Nutrition 34, 2242-2247.

Heaton, K. W. (1983). Human Nutrition: Clinical Nutrition 37c, 151-170.

Hegsted, M., Schuette, S. A., Zemel, M. B. \& Linkswiler, H. M. (1981). Journal of Nutrition 111, 553-562.

Hellendoorn, E. W. (1978). Voeding 39, 230-235.

International Union of Nutrition Sciences (1983). Nutrition Abstracts and Reviews 53, 939-1015.

IUPAC (1979), Standard Methods. Oxford: Pergamon Press.

Linkswiler, H. M., Zemel, M. B., Hegsted, M. \& Schuette, S. (1981). Federation Proceedings 40, $2429-2433$.

Miles, L. E. M., Lipschitz, D. A., Bieber, C. P. \& Cook, J. D. (1974). Analytical Biochemistry 61, $209-224$.

Moore, S. (1963). Journal of Biological Chemistry 238, 235-237.

Morris, J. N., Marr, J. W. \& Clayton, D. G. (1977). British Medical Journal ii, 1307-1314.

Noel, R. J. (1976). Journal of the Association of Official Analytical Chemists 59, $144-147$.

Raman, A. \& Chang, Y. K. (1974). Clinical Biochemistry 7, 106-111.

Rosenberg, I. H. \& Solomons, N. W. (1982). American Journal of Clinical Nutrition 35, 781-782.

Saunders, R. M. \& Betschart, A. A. (1980). American Journal of Clinical Nutrition 33, 960-961.

Schormüller, J. (1969). Handbuch der Lebensmittelchemie, vol. 4, p. 423. Berlin: Springer Verlag.

Snedecor, G. W. \& Cochran, W. G. (1967). Statistical Methods, 6th ed. Ames Iowa: lowa State University Press.

Van de Kamer J. H. (1941). Chemisch Weekblad 38, 286-288.

Van de Kamer, J. H., Gerritsma K. W. \& Wansink, E. J. (1955). Biochemical Journal 61, 174-176.

Van Dokkum, W. (1984). Dietary recommendations and mineral utlilization. PhD Thesis, University of Amsterdam.

Van Dokkum, W., Pikaar, N. A. \& Thissen, J. T. N. M. (1983). British Journal of Nutrition 50, 61-74.

Van Dokkum, W., Wesstra, A. \& Schippers, F. A. (1982). British Journal of Nutrition 47, 451-460.

Van Soest, P. J. \& Wine, R. H. (1967). Journal of the Association of Official Analytical Chemists 50, 50-55,

Wachman, A. \& Bernstein, D. S. (1968). Lancet i, 958-959.

Zaridze, D. G. (1981). Nutrition and Cancer 2, 241-249. 